\title{
6. SITES 243 AND 244
}

\author{
The Shipboard Scientific Party ${ }^{1}$
}

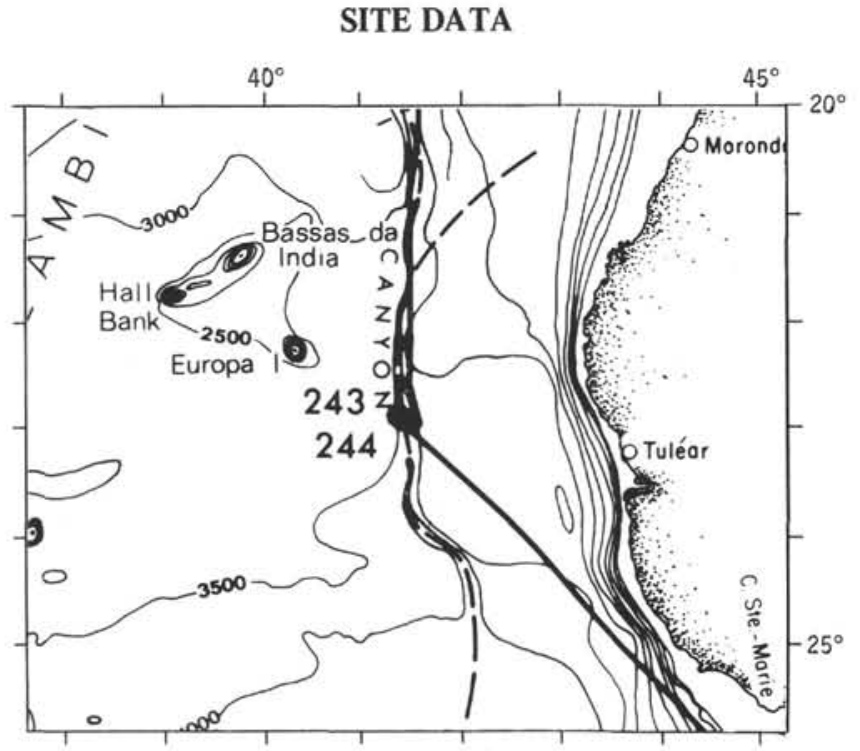

Location: Mozambique Channel (Zambesi Canyon floor [243] and flank [244])

Position:

$22^{\circ} 54.49^{\prime} \mathrm{S}, 41^{\circ} 23.99 \mathrm{E}(243)$

$22^{\circ} 55.87^{\prime} \mathrm{S}, 41^{\circ} 25.98^{\prime} \mathrm{E}(244)$

Water Depth:

3879 meters (243)

3768 meters (244)

Total Penetration:

32 meters (243)

27 meters (244)

Cores:

1 core ( $6 \mathrm{~m}$ cut, $0.3 \mathrm{~m}$ recovered) 243

1 core ( $3 \mathrm{~m}$ cut, only core catcher recovered) 244

Deepest Unit Recovered:

Sand and gravel (243)

Silty clay and coarse sand (244)

\footnotetext{
${ }^{1}$ E. S. W. Simpson, University of Capetown, Rondebosch, South Africa; Roland Schlich, Institut de Physique du Globe, Saint-Maurdes-Fossés, France; Joris Gieskes, Scripps Institution of Oceanography, La Jolla, California; W. A. Girdley, Mesa College, Grand Junction, Colorado; Lucien Leclaire, Muséum National d'Histoire Naturelle, Paris, France; B. Vaughn Marshall, U. S. Geological Survey, Menlo Park, California; Casey Moore, University of California, Santa Cruz, California; Carla Müller, Johann-WolfgangGoethe-Universität, Frankfurt, Germany; Jacques Sigal, Institut Français du Pétrole, Rueil-Malmaison, France; T. L. Vallier, Scripps Institution of Oceanography, La Jolla, California; Stan M. White, California State University, Fresno, California; Barbara Zobel, Bundesanstalt für Bodenforschung, Hannover, Germany.
}

\section{BACKGROUND AND OBJECTIVES}

Long before, and since, development of the sea floor spreading hypothesis and of modern plate tectonic concepts, a variety of predrift paleopositions and subsequent movements has been proposed for Madagascar. Most of the authors concerned have displayed their unfamiliarity with (or have found it convenient to disregard) the significance of both the similarities and differences between the structure and geological history of eastern Africa and western Madagascar, which have been summarized by Dixey (1960) and Flores (1970). An important factor contributing to the confusion is the almost complete lack of published data on the bathymetry, crustal structure, and stratigraphy of the Mozambique Channel between Mozambique and Madagascar.

Flores (1970 has published a concise account of the Phanerozoic geology of Mozambique and western Madagascar based upon his personal familiarity with both areas and access to data from deep boreholes. He summarizes the overall similarities of Karroo and Cretaceous stratigraphy in both areas but is careful to emphasize the time and space distribution of continental/marine facies transitions. In both southeastern Africa and western Madagascar, continental lacustrine, with perhaps occasional marine conditions of sedimentation was prevalent during the Permo-Carboniferous and Triassic periods, giving way during the Jurassic to widespread volcanism in the west with contemporaneous marine sedimentation in the east (Madagascar), south (Agulhas Bank), and coastal Kenya (Dixey, 1960). According to Flores (1970), during the Cretaceous the marine facies of western Madagascar changed to continental, culminating in volcanic activity during the middle Cretaceous (Turonian to Santonian/ Campanian). By contrast, the present wide Mozambique coastal plain was an area of marine sedimentation throughout the Cretaceous, becoming continental in the west. Upper Cretaceous and Tertiary marine sediments are found on both sides of the Mozambique Channel, with Late Cretaceous intrusives and late Tertiary to Quaternary volcanic activity chiefly in Madagascar and in the Mozambique Channel (Figure 1).

The general morphological features of the Mozambique Channel are shown on Figure 1, which is partly based upon an unpublished compilation of bathymetric data by Langseth, Heezen, and Ewing. To the south lies the 4500-5000-meter-deep abyssal plain in the Mozambique Basin, which is bounded on the west and east, respectively, by the Mozambique and Madagascar ridges and becomes progressively shallower northward into the Mozambique Channel. The adjacent continental slopes of Africa and Madagascar are steeply inclined down to the average depth of about 3000 meters in the Channel. The floor of the channel is deeply incised by the Zambesi Canyon and 


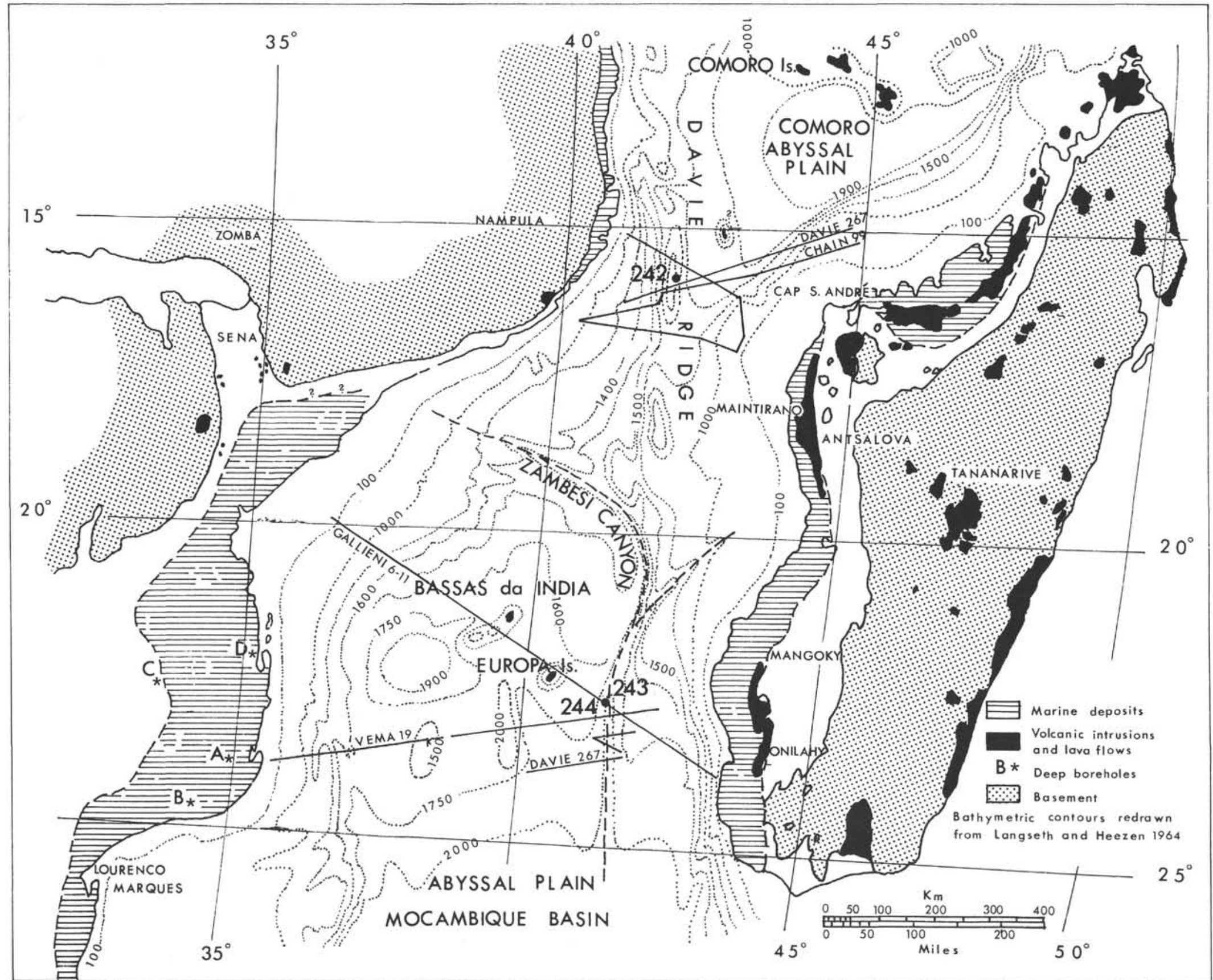

Figure 1. Map of the Mozambique Channel (slightly modified after Flores, 1970) showing the location of Sites 243 and 244, and of the seismic reflection profiles in Figures 2 and 3. 
several tributary canyons from Madagascar which effectively act as channels for the transport and dispersion of terrigenous sediment into the northern Mozambique Basin.

The Mozambique Channel is divided into two distinct basin compartments by the asymmetric (steep to the west) and weakly seismic Davie Ridge. This ridge follows the $42^{\circ} \mathrm{E}$ meridian southward until it disappears as a positive morphological feature near $19^{\circ} \mathrm{S}$, where its trend is continued southward by the lower Zambesi Canyon. Both features, each in its own way, act as effective barriers to the transport of terrigenous sediment across the channel. West of the Zambesi Canyon and the volcanic islands of Europa and Bassas da India lies the Europa Basin and abyssal plain (3500 meters), which is underlain by stratified sediments more than $1 \mathrm{sec}$ DT (double way time) thick. Between the Davie Ridge and northwestern Madagascar and extending northward to the volcanic Comoro Islands (which mark the southern boundary of the Somali Basin) lies the Comoro Abyssal Plain (3500 meters), which is similarly underlain by stratified sediments more than $1 \mathrm{sec}$ DT thick. A series of airborne magnetic profiles flown east-west across the Mozambique Channel and northern Mozambique Basin has been published by Green (1972). Except over volcanic islands, the magnetic anomalies over the channel between $10^{\circ} \mathrm{S}$ and $22^{\circ} \mathrm{S}$ (Europa Island) are below $100 \gamma$ with wavelengths between 15 and $60 \mathrm{~km}$. These contrast with the much greater amplitude and reduced wavelength of the anomalies over the Mozambique Basin between $25^{\circ} \mathrm{S}$ and $30^{\circ} \mathrm{S}$.

Reconstructions of Gondwanaland have variously placed Madagascar in three possible positions at the end of the Paleozoic before the commencement of drift:

1) Adjacent to the coast of East Africa, off Somalia, Kenya and Tanzania, followed by drift to the south and slightly east. This reconstruction is favored by du Toit (1937); Fisher, Engel, and Hilde, (1968) (who deduce that it was $20^{\circ}$ north of its present position during the Permian and that is has occupied its present position relative to Africa since the Cretaceous); Dietz and Holden (1970); McElhinny (1970); Smith and Hallam (1970); Heirtzler and Burroughs (1971) (who believe that the southward movement began since the early Cenozoic, 42-65 m.y. ago, and still continues at a rate of $2.9 \mathrm{~cm} / \mathrm{yr}$ ); and Sowerbutts (1972) (who suggests the initiation of breakup during the Cretaceous).

2) Adjacent to the pre-Cretaceous continental margin of Mozambique or Natal, with subsequent drift to the north and east. This paleoposition is advocated by Wellington (1954, 1955); Flores (1970) (commencement of drift during Early Jurassic, cessation during mid-CretaceousTuronian); Wright and McCurry (1970); Heirtzler (1971) (movement sometime since the Cretaceous); and Green (1972) (who believes that Madagascar separated from the Natal margin by east-west spreading about the Mozambique Ridge from the Late Triassic until Late Cretaceous/early Tertiary and that possible continued northward movement relative to Africa is indicated by present-day seismic activity of the Davie Ridge).

3) Present position relative to Africa has been maintained since the Paleozoic at least. This reflects the conclusion of Dixey $(1956,1960)$ (who proposed late
Carboniferous subsidence of the Mozambique Channel area resulting in the formation of a "geosyncline" and deposition of the Karroo sequence with up to $14 \mathrm{~km}$ of sedimentary rocks); Pepper and Everhart (1963); Holmes (1965); Flower and Strong (1969); and Tarling (1971).

Each of the above reconstructions has implications relating to the crustal composition and structure beneath the Mozambique Channel:

1) Movement of Madagascar southward along a transform fault structure implies, according to Heirtzler and Burroughs (1971), that basement on the east side of the Davie Ridge should be representative of the Madagascar plate and the stratigraphic section should be similar to that of eastern Kenya and Somalia.

2) Movement of Madagascar eastward away from Africa implies the presence of oceanic or thinned continental crust beneath the Mozambique Channel.

3) If no lateral movement of Madagascar relative to Africa has taken place since the Paleozoic, the channel should be underlain by a succession of terrestrial and shallow-marine sediments and volcanics transitional between the stratigraphic sections found in east southern Africa and western Madagascar.

One of the major objectives of Deep Sea Drilling Project Leg 25 was to provide essential data which would assist in the solution of this enigmatic problem; and, with this end in view, two sites located in the Mozambique Channel were selected for drilling on the basis of available data and our present meager understanding of the structure and stratigraphy of this region.

If Madagascar separated from Africa and drifted eastward, the Mozambique Channel should be underlain by oceanic or thinned continental crust covered by thick sediments shed from Africa and Madagascar. Depending on the timing of drift, the sedimentary succession should include the Tertiary, possibly also the Cretaceous, and perhaps even the Karroo, in which case thick lava successions should be included.

If, on the other hand, Madagascar has not moved relative to Africa, the mean elevation of the Mozambique Channel could be explained by the presence of similarly thick succession of supracrustal rocks resting upon continental crust of attenuated thickness (Talwani, 1962).

No seismic refraction measurement in the Mozambique Channel are available, but the Gallieni 6 flexotir profile (Figure 2) across the lower Zambesi Canyon clearly shows a prominent deep acoustic basement reflector at about 1.4 sec DT (below the canyon floor) which might be true basement or a particularly hard horizon such as the upper surface of interbedded lavas in the sedimentary sequence. Above this acoustic basement reflector, two other distinct reflecting horizons can be seen; one lies just below the floor of the 600-meter-deep Zambesi Canyon and the other is cut by the canyon. The airgun profiles made by Vema 19 and Thomas B. Davie 267 (Figure 3) show that the uppermost reflector is very prominent, particularly on the western side of the canyon.

The position selected for Sites $243 / 244$ was located in the deepest part of the Zambesi Canyon floor in order to achieve the deepest possible penetration of the sedimentary section. The objectives were (1) to sample the sediments in 


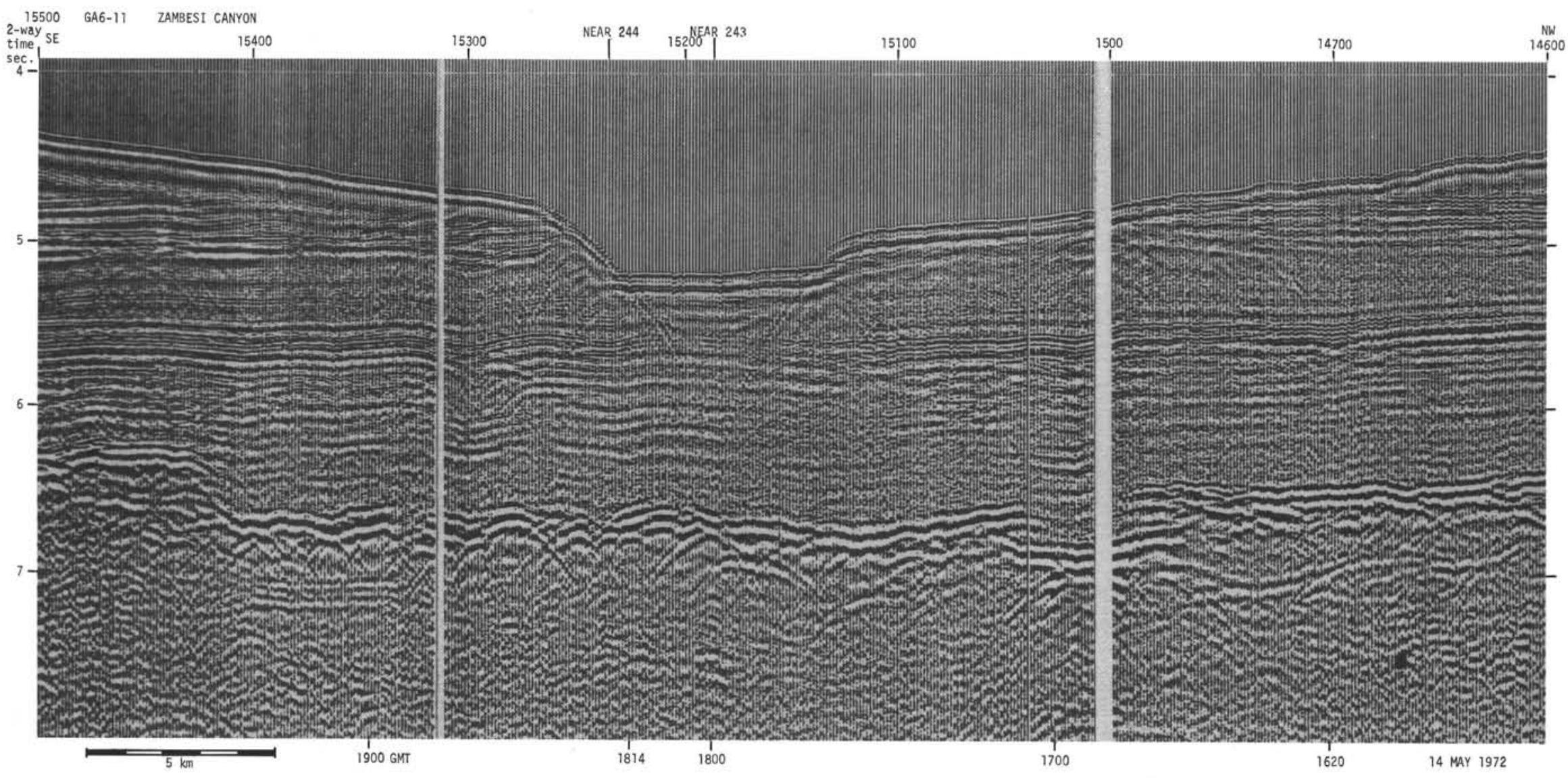

Figure 2. Gallieni 6 flexotir seismic reflection profile across the Zambesi Canyon near Sites 243 and 244 (location shown in Figure 1). Gallieni 6 records are from unpublished Institut de Physique du Globe de Paris and Comité d'Études Pétroliéres Marines data (Schlich, personal communication). 
2-way $267 / 7 \div / \pi 4$

time

sec.

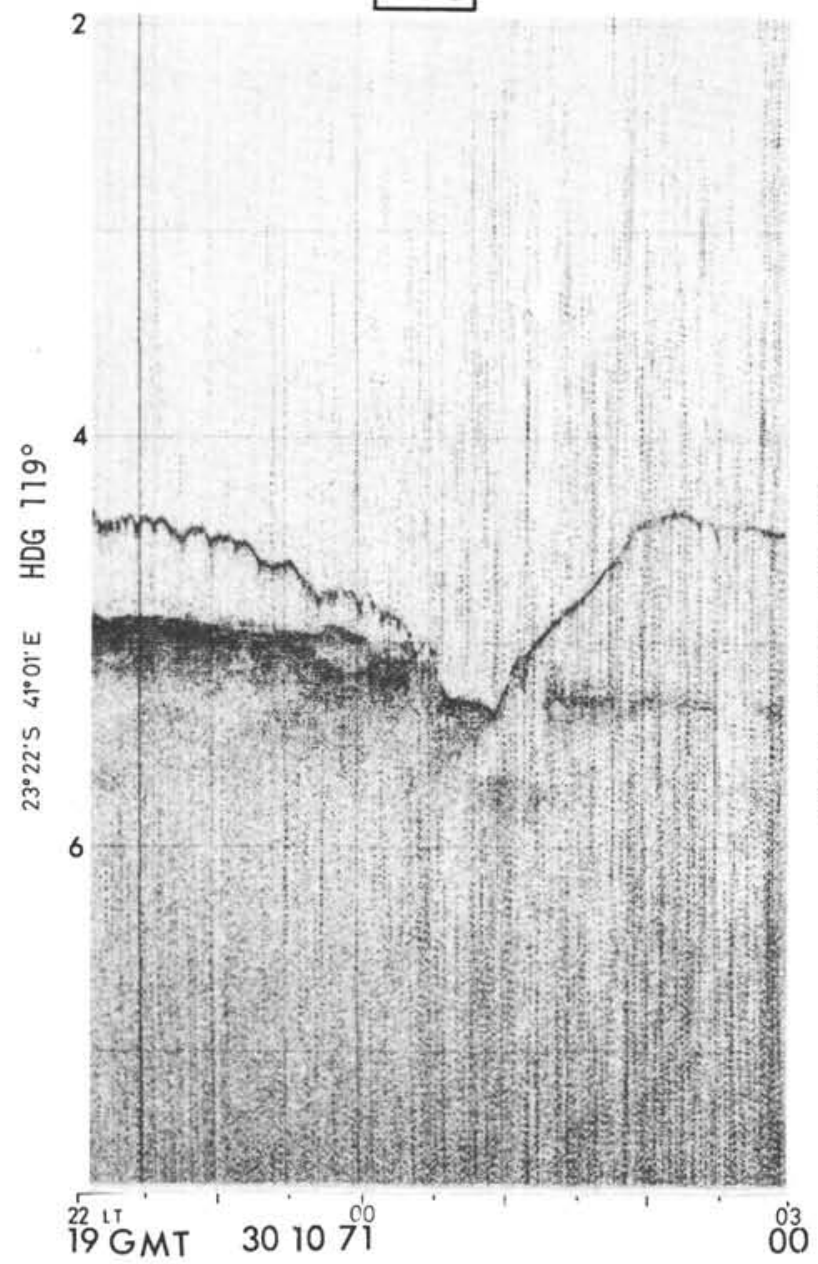

TBD $267 / 71 / T U$
TBD $267|71|$ UV

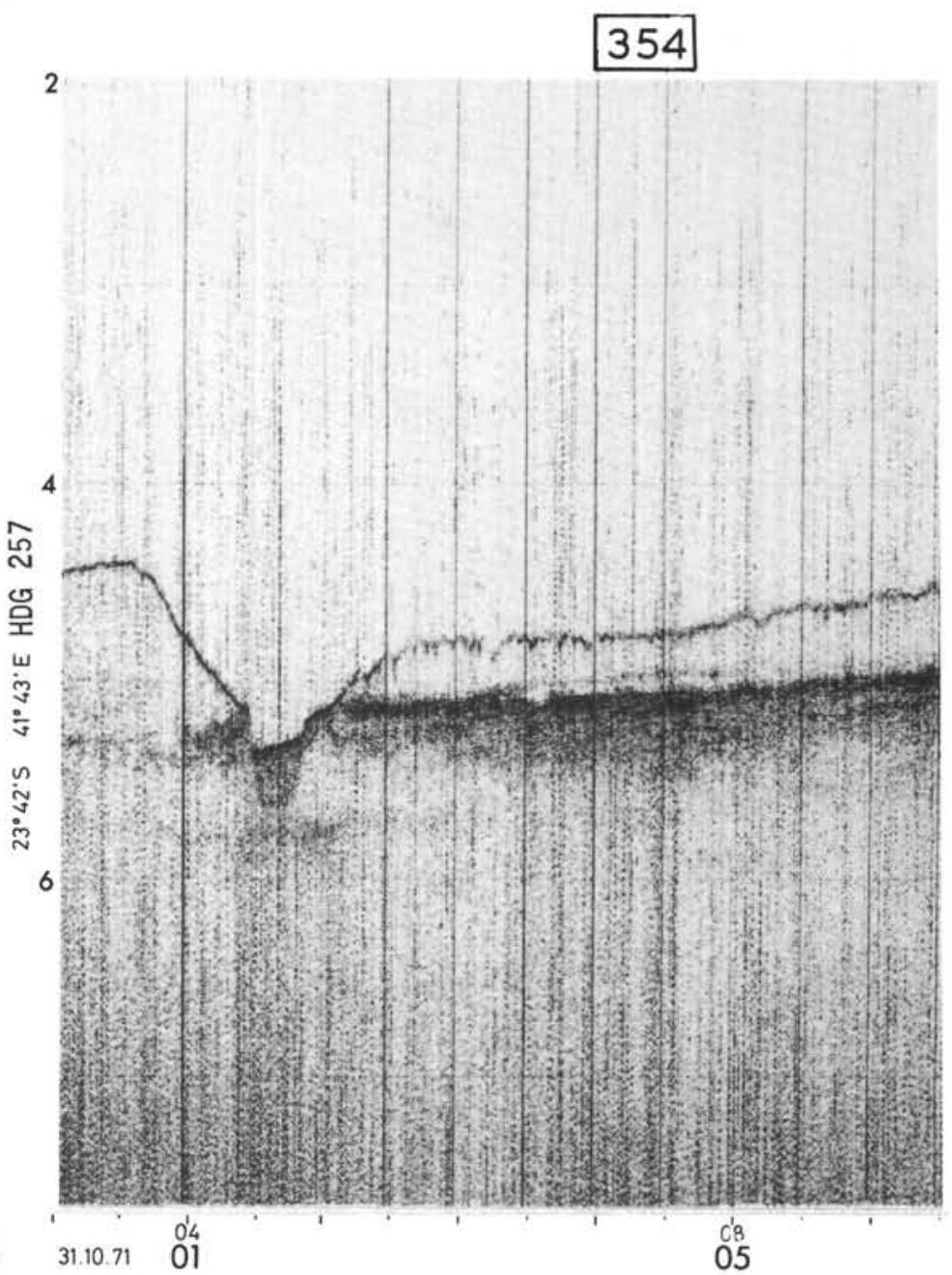

Figure 3. Thomas B. Davie 267 airgun seismic reflection profiles across the Zambesi Canyon to the south of Sites 243 and 244 (locations shown in Figure 1). Unpublished data provided by E.S.W. Simpson.

transit down the Zambesi Canyon some $800 \mathrm{~km}$ from the Zambesi River mouth, (2) to establish the deepest possible stratigraphic succession for possible correlation with the on-shore sections in Mozambique and western Madagascar and with epeirogenic events in both areas, and (3) to identify and date the prominent reflector at $1.4 \sec$ DT beneath the canyon floor.

\section{SURVEY DATA AND OPERATIONS}

Glomar Challenger departed from Site 242 at 0430 hours LT (local time) (0130 GMT) on 26 July 1972 and after 2 days and 6 hours of steaming southward down the Mozambique Channel reached a point at $22^{\circ} 58^{\prime} \mathrm{S}, 41^{\circ} 32^{\prime} \mathrm{E}$, about 8 miles east of the Zambesi Canyon; the proposed site was at $22^{\circ} 58^{\prime} \mathrm{S}, 41^{\circ} 21^{\prime} \mathrm{E}$. At $1048 \mathrm{LT}$ (0748 GMT) on 28 July 1972, Glomar Challenger changed course and Site 243 was approached along a course of about $290^{\circ}$. At the same time, the speed was reduced to 6 knots to enhance the clarity of the airgun records. At 1154 LT (0854 GMT), after having passed the east flank of the canyon and about 1 mile across the flat canyon floor, the $16-\mathrm{kHz}$ beacon was dropped under way. The airguns, hydrophones, and magnetometer were then immediately retrieved, and the ship reversed course to take up station. The geographic coordinates of Site 243 are: $22^{\circ} 54.49^{\prime} \mathrm{S}, 41^{\circ} 23.99^{\prime} \mathrm{E}$ (Figure 4).

The Glomar Challenger airgun reflection profile east of the canyon shows a thick sedimentary cover with a clear reflector at about $0.8 \mathrm{sec}$ DT rising towards the flank of the canyon. Below the canyon floor, the sedimentary sequence is strongly stratified, but no clear reflector can be seen below $0.4 \mathrm{sec}$ DT (Figure 5). The flexotir record (Figure 2) obtained by Gallieni 6, however, shows an acoustic basement reflector very clearly at about $1.4 \mathrm{sec}$ DT.

The main objective of drilling this hole was to date the oldest possible sediments in the Mozambique Channel and to obtain data on the stratigraphic history of this part of the Indian Ocean. The site was located in the floor of the 600 -meter-deep canyon to allow maximum penetration of the sedimentary sequence. A program of intermittent coring was planned: one or two cores every 100 meters with special attention being given to sample the modern 


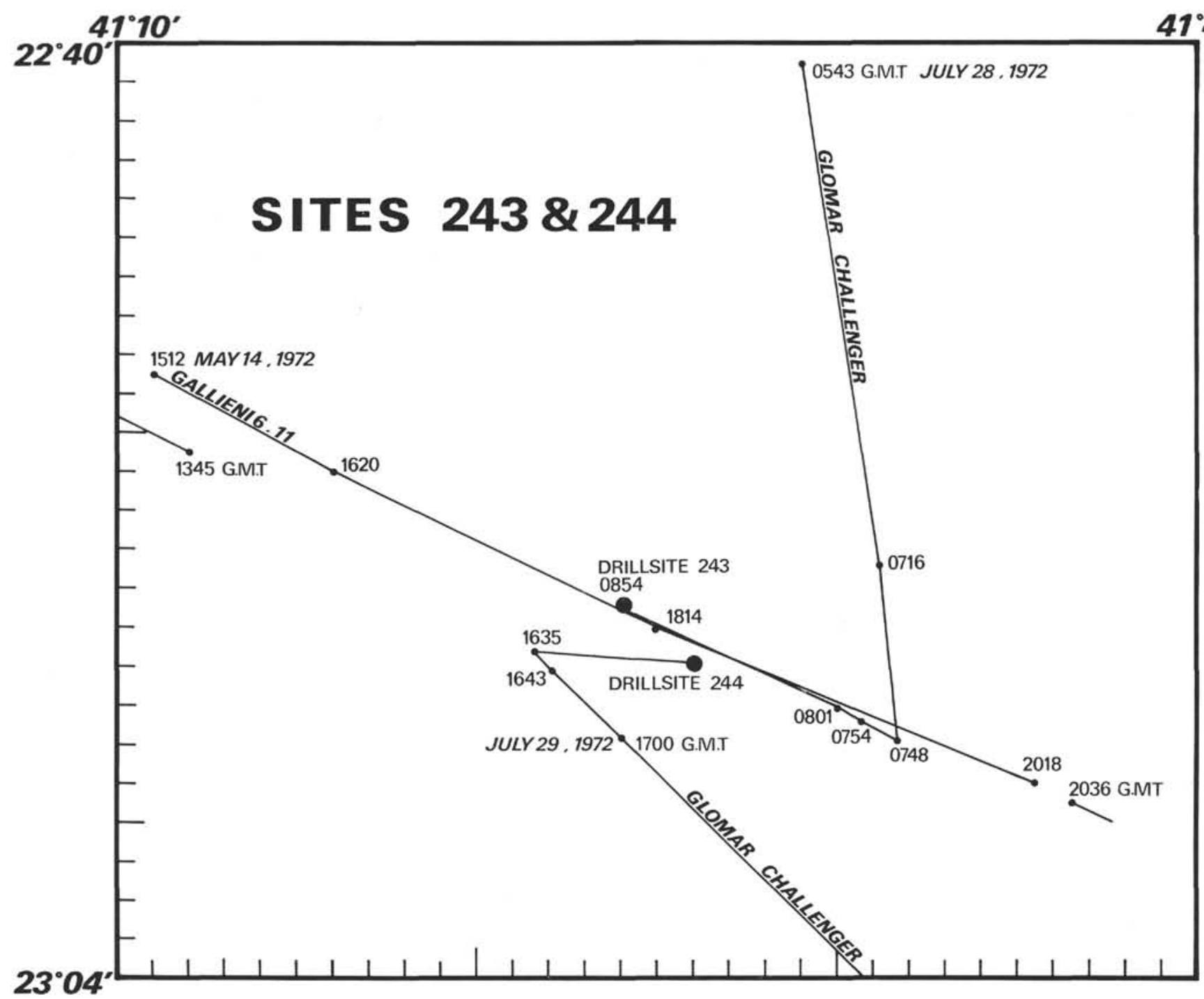

Figure 4. Details of the Glomar Challenger approach to Sites 243 and 244.

canyon fill and the reflector at $0.4 \mathrm{sec}$ DT. Since the flexotir record showed a basement acoustic reflector at about $1.4 \mathrm{sec}$ DT, it was also planned to reach this horizon if technically possible in the time available.

Drilling and coring at Site 243 started at 2150 (LT) on 28 July 1972 and ended at 2330 (LT) on 28 July 1972. Only one core with very poor recovery $(0.3 \mathrm{~m})$ was taken between 0-6 meters below the sea floor (Table 1). At a depth of 32 meters it was decided, for technical reasons relating to hole instability, to abandon the site. The total time spent on Site 243 was about 13 hours.

A decision was made to drill a new site in the same area on the east slope of the canyon and Glomar Challenger left Site 243 at 0030 LT (2130 GMT) headed in a southeasterly direction at a speed of $1 \mathrm{knot}$, with the drill pipe suspended 150 meters above the mud line.

At about 2.4 miles to the southeast of Site 243, a suitable location on the east flank of the Zambesi Canyon was reached, and a $13.5-\mathrm{kHz}$ beacon was dropped at 0330 LT (0030 GMT) on 29 July 1972 above the identified site.
Glomar Challenger then took up station with a beacon offset of 1400 feet to the east to enhance the PDR bottom reflection. The geographical coordinates of Site 244 are: $22^{\circ} 55.87^{\prime} \mathrm{S}, 41^{\circ} 25.98^{\prime} \mathrm{E}$ (Figure 4).

The seismic reflection profiles obtained at this site have been described above. Due to side echoes, the water depth at Site 244 was difficult to determine. Several echoes were observed between 3778 and 3893 meters; finally the bottom was felt at a depth of 3857 meters.

Drilling and coring started at this site at 0800 (LT) on 29 July 1972 and ended at 1130 (LT) on the same day. For reasons similar to those stated above for Site 243, penetration appeared to be very difficult. Only one core catcher sample (Table 2), at a depth of 3 meters, was obtained, and at a depth of 27 meters, the decision was made to abandon the site because of hole stability problems. After retrieving the drill string, the four-cone bit, the float sub with the float valve, and the lower bearing assembly for the core barrel, the drill collar and the inner core barrel were missing. 


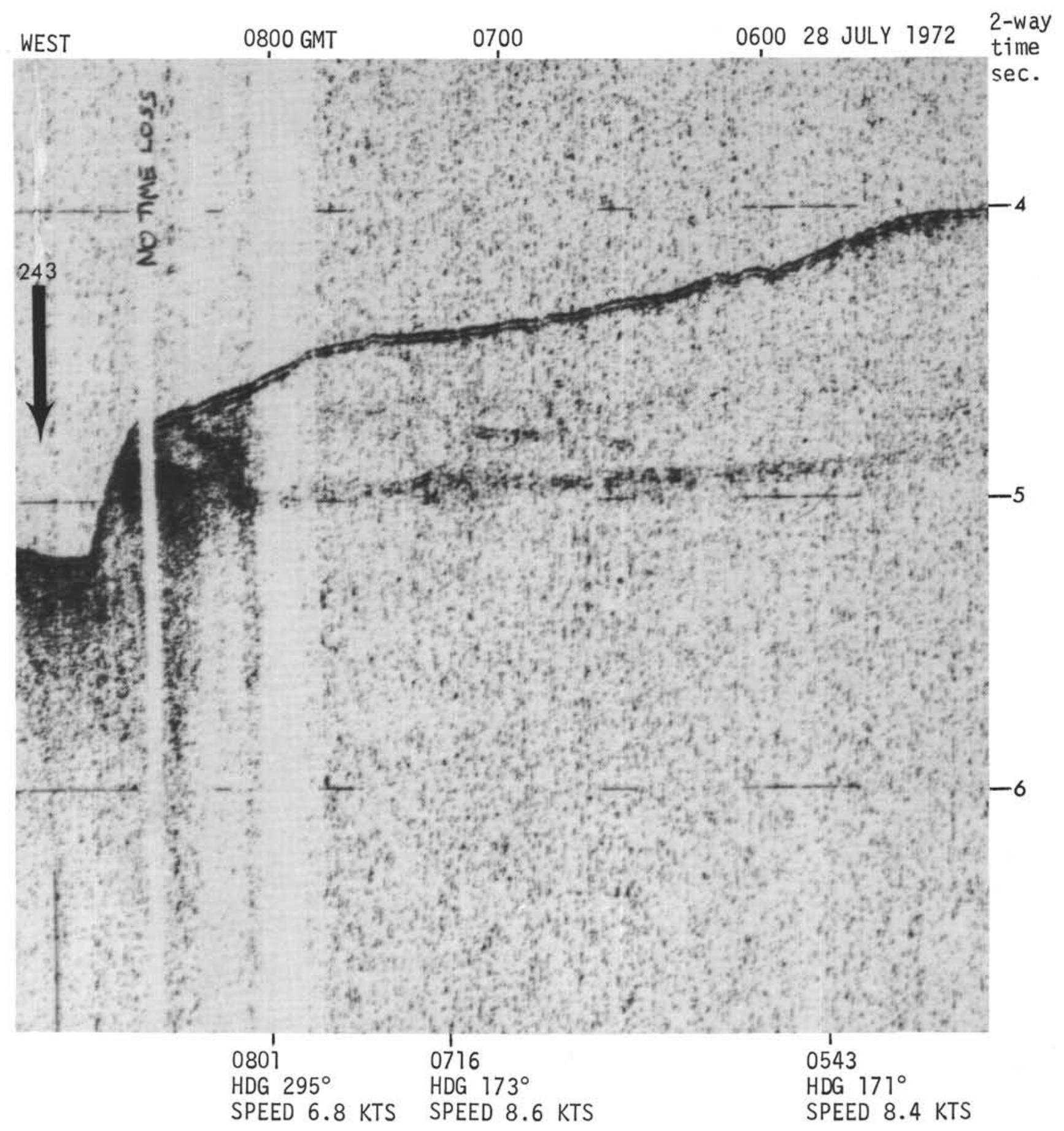

Figure 5. Glomar Challenger seismic reflection profile on approach to Site 243.

TABLE 1

Coring Summary, Site 243

\begin{tabular}{ccccc}
\hline Core & $\begin{array}{c}\text { Depth Below } \\
\text { Sea Floor } \\
(\mathrm{m})\end{array}$ & $\begin{array}{c}\text { Cored } \\
(\mathrm{m})\end{array}$ & $\begin{array}{c}\text { Recovered } \\
(\mathrm{m})\end{array}$ & $\begin{array}{c}\text { Recovery } \\
(\%)\end{array}$ \\
\hline 1 & $0-6$ & 6 & 0.3 & 5 \\
Total & & 6 & 0.3 & 5 \\
\hline
\end{tabular}

Note: Echo sounding depth (to drill floor) $=3889$ meters; drill pipe length to bottom $=3887$ meters .
TABLE 2

Coring Summary, Site 244

\begin{tabular}{lcccc}
\hline Core & $\begin{array}{c}\text { Depth Below } \\
\text { Sea Floor } \\
(\mathrm{m})\end{array}$ & $\begin{array}{c}\text { Cored } \\
(\mathrm{m})\end{array}$ & $\begin{array}{c}\text { Recovered } \\
(\mathrm{m})\end{array}$ & $\begin{array}{c}\text { Recovery } \\
(\%)\end{array}$ \\
\hline 1 & $0-3$ & 3 & CC & 0 \\
Total & & 3 & CC & 0 \\
\hline
\end{tabular}

Note: Echo sounding depth (to drill floor) $=3778$ to 3893 meters; drill pipe length to bottom $=3857$ meters. 
Glomar Challenger departed from Site 244 at 1817 LT (1517 GMT) on 29 July 1972 in a northeast direction at a speed of about 6 knots while the airguns, hydrophones, and magnetometer were streamed. At a distance of about 1.5 miles from the beacon, the ship changed course to about $245^{\circ}$. The beacon was passed at $1858 \mathrm{LT}$ (1558 GMT), and the course was slightly altered to $274^{\circ}$ at the same time. The seismic reflection profile was continued in the same direction for four miles at the same speed. After having crossed the western slope of the canyon at 1935 LT (1635 GMT), Glomar Challenger changed course to $135^{\circ}$ and steamed at maximum speed in the direction of Site 245 .

\section{LITHOLOGY}

\section{Site 243}

At Site 243, drilling and coring was attempted in a hole located near the center of the channel floor of the Zambesi Submarine Canyon. Only a core catcher sample and 0.3 meter of a punch core were retrieved before the site was abandoned because of poor hole stability.

Texturally, the sample is a sub- to well-rounded, coarse/very coarse sand and fine gravel. The mean size is in the very coarse sand $(1-2 \mathrm{~mm})$ range; the maximum size being a $1.5-\mathrm{cm}$, well-rounded feldspar grain. Compositionally, the sample consists of 95 percent quartz, 2 percent feldspar, 2 percent rock fragments (granite and quartzite), and 1 percent accessory components. In this latter category, shell fragments, garnet grains, and foraminifera (Pleistocene-Recent) were recorded. One pebble-sized rock fragment (shale?) yielded late Eocene nannofossils.

The site is located about $800 \mathrm{~km}$ from the mouth of the Zambesi River at Chinde on the coast of Mozambique and about $200 \mathrm{~km}$ down-canyon from the confluence of a tributary canyon. This tributary canyon extends $250 \mathrm{~km}$ northeastward toward the continental shelf of western Madagascar.

The Zambesi River originates in Angola, $2800 \mathrm{~km}$ from the site and is the largest and longest river in southeastern Africa. The rocks underlying the very large drainage area range in age from the oldest known $\left(3.4 \times 10^{9}\right.$ m.y. $)$ Precambrian to the Cenozoic of the East African coastal plain. Compositions of these rocks range from high-grade metamorphic migmatites and granites to a wide variety of sedimentary rocks and volcanics. The area of western Madagascar adjacent to the tributary submarine canyon has a similar set of rock ages and provenance characteristics.

The large grain size in the sample recovered from the canyon fill is a function of the competence of down-canyon flow mechanisms, while the high degree of rounding and the relatively high mineral (compositional) maturity can be attributed to several factors present in the Zambesi River Submarine Canyon system. These include: a long transport distance (Africa or Madagascar) with accompanying in-transit attrition, a high degree of weathering completeness in the provenance areas, the rock types of the provenance areas, possible winnowing effects by marine sedimentation agents adjacent to the Zambesi River mouth or on the continental shelf of western Madagascar, and the sedimentation characteristics of turbidity currents operating in the Zambesi Submarine Canyon system.
Because of the small sample size recovered, the role of these factors or any additional factors in determining the sediment characteristics cannot be fully evaluated.

\section{Site 244}

Site 244, 2.4 miles to the southeast of Site 243, is located on the east flank of the Zambesi River Submarine Canyon. A drilling and coring program was planned in order to obtain a deep vertical lithologic section of this part of the Mozambique Channel. As in Site 243, sediment conditions created poor hole stability, and this site was abandoned after retrieving only an initial core catcher sample.

The sample consisted of a greenish-gray clay/silty clay with some associated sands and gravels. The sand/gravel component consisted of 60 percent medium to very coarse sand and 40 percent granule-pebble fraction. The mean size was in the very coarse sand $(1-2 \mathrm{~mm})$ range; the maximum size being a $1-\mathrm{cm}$ quartz grain. Grains are subangular in the smaller size range (medium sand) and are sub- to well-rounded in the larger size fractions. Compositionally, the sand/gravel sample consists of 90 percent quartz, 5-7 percent feldspar, and 3-5 percent accessory components, which include rock fragments (granite), shell fragments, and a trace amount of heavies (garnet). In general, the visual and compositional characteristics of this sample are very similar to those of the sand/gravel recovered at Site 243.

The clay/silty clay component consists of 65 to 75 percent clay minerals, 2 to 5 percent authigenic pyrite and carbonate rhombs, and 25 percent of a detrital fraction which includes quartz, feldspar, accessory minerals (rutile, garnet), and foraminifera (Pleistocene-Recent).

Ages of the fossils within the sediment and the similarity of the sand/gravel component to that recovered at Site 243 indicate that the sample recovered from Site 244 was involved in Pleistocene to Recent transportation by down-canyon turbidity flows, and the material was subsequently deposited against the older sediments of the Zambesi River Submarine Canyon flank.

\section{SUMMARY AND CONCLUSIONS}

Both sites are located about three miles apart near $22^{\circ} 55^{\prime} \mathrm{S}, 41^{\circ} 25^{\prime} \mathrm{E}$ in the Zambesi Canyon, which forms a channel about 600 meters deep in this area. The purpose of drilling in the deep canyon floor was to achieve maximum possible penetration into the thick sediments of the southeastern Mozambique Channel for (a) comparison with on-shore stratigraphic successions in Madagascar and Mozambique, and (b) identification of a prominent acoustic reflector at a depth of $1.4 \mathrm{sec}$ DT beneath the canyon floor.

Drilling and coring at Site 243, in the floor of the canyon at a depth of 3879 meters, commenced at 2150 LT and ended at 2330 LT on 28 July 1972 . Only one punch core, with very poor recovery $(0.3 \mathrm{~m})$, was taken between 0 and 6 meters below the sea floor. After penetration to 32 meters in unconsolidated coarse sand and fine gravel, it was decided, for technical reasons relating to instability of the hole, to abandon the site and to attempt another hole in the eastern lower slope of the canyon. The second site (244) is situated about 2.4 miles southeast of the first. Drilling and coring at Site 244 , in a water depth of 3768 
meters, commenced at $0800 \mathrm{LT}$ and ended at $1130 \mathrm{LT}$ on 29 July 1972 . Only a core catcher sample at a depth of 3 meters was obtained, and after 27 meters penetration, the site was abandoned due to hole stability problems which caused the loss of the bit, float sub, drill collar, and inner core barrel.

The major objective, to penetrate and sample deep beneath the floor of the Zambesi Canyon, was not realized for technical reasons, but the nature of the small sediment samples is of interest. The 0.3 -meter punch core sample from the canyon floor (Hole 243) consists of unsorted subto well-rounded, coarse to very coarse sand and fine gravel with a mean size in the $1-2 \mathrm{~mm}$ range; the maximum size recovered is represented by a $1.5 \mathrm{~cm}$, well-rounded feldspar pebble. The composition of the sediment is 95 percent quartz, 2 percent feldspar, 2 percent rock fragments (granite and quartzite) and 1 percent accessories (including shell fragments, garnet grains, and Pleistocene/Recent foraminifera). An argillite pebble yielded late Eocene nannofossils.

The site is located about 800 kilometers down-canyon from the mouth of the great Zambesi River at Chinde on the coast of Mozambique, and about 200 kilometers from the confluence of a tributary canyon (see Figure 1) which extends 250 kilometers northeastward toward the continental shelf of western Madagascar and the mouth of the Tsiribihina River. Both the latter and the Zambesi River are among the largest which drain the ancient Precambrian highland terrain of Madagascar and southern Africa, respectively.

At nearby Site 244 , located on the eastern wall of the Zambesi Canyon about 30 meters above the canyon floor, the small punch core sample consists of greenish-gray clay and silty clay with some associated sand and gravel that are similar to the canyon floor sample at Site 243 . The sample consists of $65-75$ percent clay minerals, 2-5 percent authigenic pyrite and carbonate rhombs, and 25 percent detrital quartz, feldspar, rutile, garnet, and Pleistocene/ Recent foraminifera. The whole sample clearly represents material that is in transit down the canyon towards the Mozambique Basin.

The coarse sand and gravel samples recovered from both Sites 243 and 244 indicate that laterally-confined turbidity currents are capable of transporting detrital material which is at least $1.5 \mathrm{~cm}$ in diameter $800 \mathrm{~km}$ from the nearest source, and that similarly large grain sizes are occasionally swept up by turbulence (if not normally transported) at least to 30 meters above the floor of the canyon.

Experience at these sites indicates that consideration should be given to the development of deep-sea drilling techniques for supporting the bottom-hole assembly in unconsolidated sand and gravel in order that advantage may be taken of natural deep channels to achieve maximum stratigraphic penetration.

\section{REFERENCES}

Dietz, R. and Holden, J. C., 1970. Reconstruction of Pangea: breakup and dispersion of continents, Permian to Present: J. Geophys. Res., v. 75, p. 4939.

Dixey, F., 1956. The East African Rift System: Bull. Colonial Geol. Min. Res., Suppl. 1.

1960. The geology and geomorphology of Madagascar and a comparison with eastern Africa: Geol. Soc. London, Quart. J., v. 116, p. 255-268.

du Toit, A. L., 1937. Our Wandering Continents: Edinburgh (Oliver \& Boyd).

Fisher, R. L., Engel, C. G., and Hilde, T. W. C., 1968. Basalts dredged from the Amirante Ridge, western Indian Ocean. Deep Sea Res., v. 15, p. 521-534.

Flores, G., 1970. Suggested origin of the Mozambique Channel: Geol. Soc. S. Africa Trans., v. 73, p. 1-16.

Flower, M. F. J. and Strong, D. F., 1969. The significance of sandstone inclusions in lavas of the Comores Archipelago: Earth Planet. Sci. Lett., v. 7, p. 47.

Green, A. G., 1972. Seafloor spreading in the Mozambique Channel: Nature, v. 236, p. 19-21.

Heirtzler, J. R., 1971. The evolution of the southern oceans. In Quam, L. O. (Ed.), Research in the Antarctic: Am. Assoc. Adv. Sci., Washington, D. C.

Heirtzler, J. R. and Burroughs, R. H., 1971. Madagascar's paleoposition: new data from the Mozambique Channel: Science, v. 174, p. 488-490.

Holmes, A., 1965. Principles of physical geology. New York (Ronald Press).

McElhinny, M. W., 1970. Formation of the Indian Ocean: Nature, v. 228 , p. 977.

Pepper, J. F. and Everhart, G. M., 1963. Misc. Geol. Invest. Map I-380, (U. S. Geol. Surv.).

Smith, A. G. and Hallam, A., 1970. The fit of the southern continents: Nature, v. 225 , p. 139-144.

Sowerbutts, W. T. C., 1972. Rifting in eastern Africa and the fragmentation of Gondwanaland: Nature, v. 235, p. 435-437.

Talwani, M., 1962. Gravity measurements on H.M.S. Acheron in South Atlantic and Indian oceans: Geol. Soc. Am. Bull., v. 73, p. 1171-1182.

Tarling, D. H., 1971. Gondwanaland, palaeomagnetism and continental drift: Nature, v. 229, p. 17-21.

Wellington, J. H., 1954. The significance of the lower Zambesi course: S. African J. Sci.

1955. Southern Africa: a geographical study: Cambridge, England (Cambridge Univ. Press).

Wright, J. B. and McCurry, P., 1970. The significance of sandstone inclusions in lavas of the Comores Archipelago, Flower, M. F. J. and Strong, D. F. (letter to the editor): Earth Planet. Sci. Lett., v. 8, p. 267. 

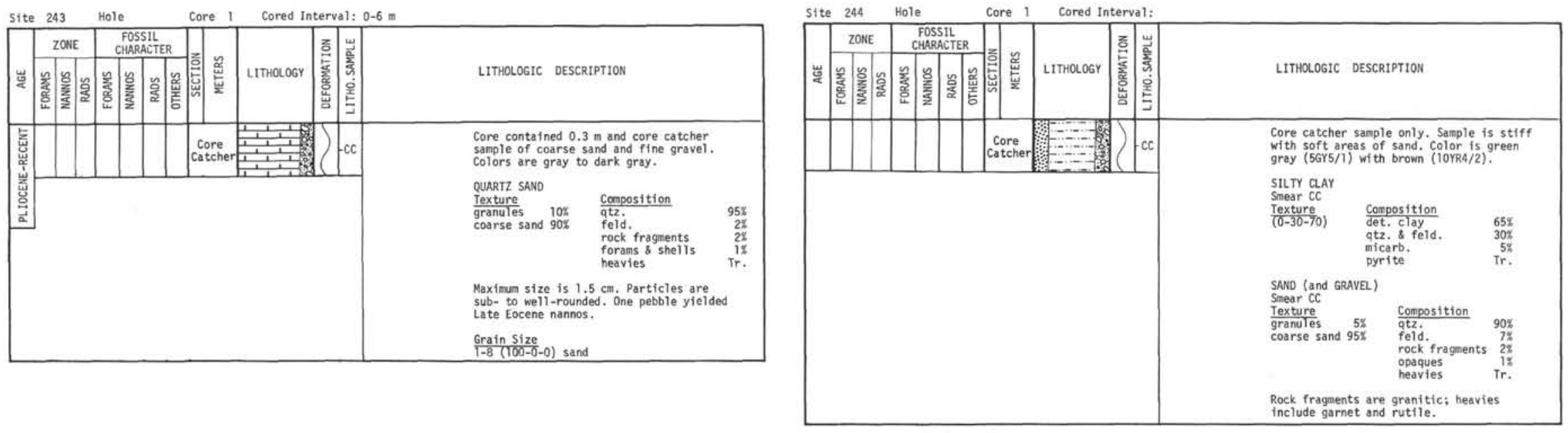